\title{
BLENDED LEARNING AND STUDY EFFECTIVENESS
}

\author{
Dr. Viktorija Sulčič, UP Faculty of management Koper, viktorija.sulcic@fm-kp.si \\ Dr. Dušan Lesjak, UP Faculty of management Koper, dusan.lesjak@fm-kp.si
}

\begin{abstract}
After the initial e-learning enthusiasm, we have finally reached a stage of sobriety (similar to the burst of the dot.com bubble in business). The research results presented in the paper bellow showed that ICT per se does not improve e-learning effectiveness. In the paper, a case of blended learning approach in higher education is presented. The presentation is part of a wider research made by our institution, which showed that only using different teaching strategies (methods of teaching and learning) from those used in traditional education can improve study effectiveness in e-learning.
\end{abstract}

\section{Key words}

E-learning, Blended learning, Study effectiveness, Higher education

\section{PROS AND CONS OF E-LEARNING}

E-learning is learning during which students get their study materials through electronic media (internet, intranet, extranet, satellites, audio/video equipment, CDs) (InternetTime Group). The term e-learning was first used at the time when the Internet became widely used for business and personal purposes. On the other hand, information and communication technology (ICT) in education had been used long before that. First, ICT was used as a support tool in education processes by institutions that were offering distance education (DE), because ICT overcame the obstacles caused by time and spatial separation of participants in education. That is why for some DE (especially DE through the internet) is still a synonym for e-learning, which is not true. E-learning can be carried out in lecture-rooms - without the spatial separation of participants or as a distance learning, when the participants are separated in space, and, very often, also separated in time.

Educational institutions are not alone in providing learning through the Internet (online learning). In companies, employees often use intranets, the Internet or extranets for learning purposes.

E-learning provides many benefits, especially for the learners. ICT enables customisation of education to the needs and abilities of participants, i.e. to customers of educational services. There we can speak about the adaptation of services to the needs of customers, which is also a trend in the business world.

E-learning is becoming increasingly interesting for the society and educational institutions because it introduces the concept of lifelong learning [18] and because knowledge is becoming more and more important, both in Slovenia [14, 15] and abroad [19], which increases demand for various educational forms. In Slovenia, enrolment in higher education institutions between 2000 and 2004 increased faster than in other EU states, and reached on average 5.6 $\%$ annually (compared to the EU 25 with $3.3 \%$ and in the EU 15 with the average $2.4 \%$ annual increase) [6]. Increased demand for different education programmes worldwide is catered for by educational institutions, which offer new forms of education that are frequently supported by ICT, and, above all, the Internet. The e-learning market in North America is the fastest growing market [7]. Substantial growth (85\% average annual growth) of expenses for eeducation was also forecasted by the IDC [8] in 2003.

But weaknesses of e-education should also be pointed out. Growing e-learning and e-courses market does not mean that the education supply is being improved and that the possibilities for acquiring new knowledge are becoming more varied. According to research carried out by Overton [12], for example, 60 $\%$ of projects related to e-learning introduction in British business environments were unsuccessful. Further on, Mungania [10] states in her research related to barriers in e-learning that $70 \%$ of participants in e-learning, which is carried out in American companies, are for various reasons unlikely to finish their e-learning. With regard to technological complexity of e-learning such lack of success represents, on the one hand, negative promotion for e-learning in general and, on the other hand, economically unjustified investment on the part of the education provider.

Despite the fact that ICT represents the fundamental material condition for e-learning, it does not have a statistically significant influence on the effectiveness of e-learning. In 1983, Clark [3] expressed doubts by claiming that ICT represents only the medium for the materials distribution and not the means for the 
improvement of learning outcomes. Similar results are found in the detailed study of Russell $[13,11]$ who found out that there are no statistically significant differences between classical and online learning. Therefore Russell suggested that classical contents (courses) should be adequately adapted for e-delivery [13, xiii].

Ally [1] found out that teaching strategies, i.e. methods and ways of teaching as well as testing and assessment methods are much more important than the use of ICT in education. Teaching strategies depend on a number of factors, above all on the participants in education, the level of education, contents and the purpose of education (e.g. formal or informal education).

In their research on the reasons for huge dropout rates in online education, Dagger and Wade [4] ascribed it to student non-participation in the learning process. Even the introduction of adapted multimedia materials did not improve student success rates, which further confirms the importance of teaching methods in on-line education.

E-learning differs from traditional education in that it includes ICT in the learning process. Due to some disadvantages of online learning (feeling of isolation, lack of interaction with fellow students and teachers, huge dropout) we decided to blend online learning with traditional forms of learning. In our case, we used an e-classroom, which was the name given to the web-based course management system Moodle (www.moodle.org). When outlining the course delivery we planned to combine face-to-face meetings with e-classroom activities. The frequency of face-to-face meetings depends on the type of course and the type of study. For compulsory courses, attended by full-time students, we planned $50 \%$ of face-to-face sessions, whereas for part-time students we planned only 2 face-to-face sessions in eight weeks, namely the introductory meeting and the last session.

In our research, the following hypotheses were tested:

H1: E-learning requires a renewal of the learning process - courses should be delivered by using different teaching strategies.

$\mathrm{H} 2$ : Blended delivery enables students to acquire more knowledge and different knowledge than in traditionally delivered courses.

H3: Students, who have the opportunity to experience more face-to-face sessions with their fellow students and teachers become more effective than their fellow students, who are deprived of such opportunities.
These hypotheses will be tested on a population of students, enroled in a business school in the tertiary level of education. The research was carried out with students studying a compulsory course as well as an elective course. We shall only describe the part of our research, which relates to the mode of delivery of elearning.

\section{BLENDED E-LEARNING}

The combination of face-to-face and online sessions was not the only difference, which was introduced in our education process. We tried to make a detailed plan of all student activities when preparing the plan for the course delivery, taking into account criteria for credit assignment to courses according to ECTS (European Credit Transfer and Accumulation System), which states that an average student (for an average grade) should invest between 25 and 30 hours of their work for 1 ECTS. The study load includes face-to-face sessions, independent work at home or at school - the study of literature, home assignments, rehearsal, group work - planning and guiding group work, field work and other activities stated in the delivery plan for a certain course, as well as assessment and testing.

\section{Research methodology}

The suitability of blended e-learning was studied using data collected during the course delivery and thus summarise the characteristics of the delivery itself. Next, we studied the influence of these characteristics for the course evaluation and the opinion about the acquired knowledge as the output of the education process (the influence on the effectiveness of the education process).

Data were collected by means of questionnaires, which were delivered to polled students electronically (through the e-classroom). Our contribution shows the results of our research that was carried out during the academic year 2005/2006 among the students attending the E-business course (elective course, 6 ECTS, 109 students enroled, average response $94.5 \%$ ) and among the students attending the Business informatics course (compulsory course, 4 ECTS, 125 students enroled, average response rate $78.0 \%$ ).

Data gathered from e-questionnaires were entered in Excel and later imported in SPSS. During data processing we used methods of descriptive statistics and the method of correlation together with the method of linear regression (Stepwise method). Because the blended method of study was dealt with 
from various viewpoints, we grouped individual variables due to their large number. If calculated parameters allowed (Alpha $<0.80$; KMO $<0.6$; Bartlett test: Sig. $>0.05)$, we grouped variables by means of the method of main components.

\section{Data analysis}

Activities in the e-classroom required from the students to access the e-classroom at least three times. Taking into account that all students do not have their own computer during their studies in their temporary place of residence, we arranged that students had open access to the computer room at least for two hours per day. Place and frequency of eclassroom access, days and time of on-line access was checked by means of the end-of-course feedback.

Table 1. Access to e-classroom

\begin{tabular}{|c|c|c|c|c|c|c|c|}
\hline \multirow{3}{*}{ Variables } & \multirow{3}{*}{ Features } & \multicolumn{4}{|c|}{$\mathbf{E S}$} & \multirow{2}{*}{\multicolumn{2}{|c|}{$\begin{array}{l}\text { CS } \\
\text { FT }\end{array}$}} \\
\hline & & \multicolumn{2}{|c|}{ FT } & \multicolumn{2}{|c|}{ PT } & & \\
\hline & & $\#$ & $\%$ & \# & $\%$ & $\#$ & $\%$ \\
\hline \multirow{5}{*}{ Access to e-classroom } & Only from home & 10 & 16.7 & 11 & 27.5 & 10 & 11.1 \\
\hline & Mainly from home & 34 & 56.7 & 17 & 42.5 & 52 & 57.8 \\
\hline & Mainly from school/office & 12 & 20.0 & 11 & 27.5 & 17 & 18.9 \\
\hline & Only from school/office & 2 & 3.3 & 1 & 2.5 & 7 & 7.8 \\
\hline & From elsewhere & 2 & 3.3 & & & 4 & 4.4 \\
\hline \multirow{4}{*}{$\begin{array}{l}\text { Frequency of e- } \\
\text { classroom access }\end{array}$} & Every day & 30 & 50.0 & 26 & 65.0 & 13 & 14.4 \\
\hline & More than 3 times a week & 24 & 40.0 & 13 & 32.5 & 48 & 53.4 \\
\hline & 1-3 times a week & 6 & 10.0 & 1 & 2.5 & 28 & 31.1 \\
\hline & Once a week & & & & & 1 & 1.1 \\
\hline \multirow{3}{*}{$\begin{array}{l}\text { Days of e-classroom } \\
\text { access }\end{array}$} & During working days & 5 & 8.3 & 6 & 15.8 & 24 & 27.6 \\
\hline & During week-ends & 6 & 10.0 & 1 & 2.6 & 10 & 11.5 \\
\hline & Whenever & 49 & 81.7 & 31 & 81.6 & 53 & 60.9 \\
\hline \multirow{5}{*}{$\begin{array}{l}\text { Time of e-classroom } \\
\text { access }\end{array}$} & In the morning & 4 & 6.7 & 5 & 12.5 & 6 & 6.7 \\
\hline & In the afternoon & 13 & 21.7 & 4 & 10.0 & 17 & 18.9 \\
\hline & In the evening & 11 & 18.3 & 9 & 22.5 & 13 & 14.4 \\
\hline & Late at night & 32 & 53.3 & 6 & 15.0 & 3 & 3.3 \\
\hline & Regardless of the time of the day & & & & & 51 & 56.7 \\
\hline
\end{tabular}

Legend: ES - elective course, CS - compulsory course, FT - full time students, PT - part-time students

As seen from the Table 1, the majority of students accessed e-classroom from their homes (elective course: $73.4 \%$ of students on full-time study, $70.0 \%$ of students on part-time study, compulsory course: $68.9 \%$ ), every day, and regardless of the day of the week or the time of the day.

Part-time students attending the elective course most keenly accepted the e-classroom.

Students attending the elective course believed that the e-classroom was simple to use, well designed and it represented a pleasant learning environment (Table $2)$. Differences are statistically significant $(\mathrm{P}<0.05)$. Statistically significant are also the differences between students on part-time studies attending the elective course $(\mathrm{P}<0.05)$, which means that the eclassroom was more keenly accepted by students attending the elective course and by part-time students.
Table 2. Opinion of students about e-classroom

\begin{tabular}{lccccc}
\hline $\begin{array}{l}\text { On-line } \\
\text { classroom is... }\end{array}$ & FT & PT & FT & t-test - P & t-test - P \\
\hline $\begin{array}{l}\text {.. a pleasant } \\
\text { environment. } \\
\text {.. easy to use. }\end{array}$ & 4.1 & 4.6 & 3.9 & 0.00 & 0.00 \\
$\begin{array}{l}\text {. well- } \\
\text { designed. }\end{array}$ & 4.2 & 4.5 & 3.7 & 0.00 & 0.00 \\
\hline Average & $\mathbf{4 . 2}$ & $\mathbf{4 . 5}$ & $\mathbf{3 . 8}$ & $\mathbf{0 . 0 0}$ & $\mathbf{0 . 0 0}$ \\
\hline
\end{tabular}

Legend: EC - elective course, $\mathrm{CC}$ - compulsory course, FT - full time students, PT - part-time students

By using the method of principle components we formed a new variable, which explains a $79.35 \%$ variance of combined variables.

Statistically significant differences among students can also be noticed with regard to the opinion about 
materials (Table 3). Above all, there are differences among students studying full-time and part-time and students attending elective and compulsory course. For students attending the compulsory course materials were significantly less understandable than for students attending the elective course, despite the fact that they were prepared by the same author. In order to get opinions on materials, a new variable was introduced in the form of an average of all three variables.

Table 3. Opinion on materials

\begin{tabular}{|c|c|c|c|c|c|}
\hline \multirow{2}{*}{$\begin{array}{l}\text { Materials } \\
\text { were... }\end{array}$} & \multicolumn{2}{|c|}{$\mathbf{E C}$} & \multirow{2}{*}{$\begin{array}{l}\text { CC } \\
\text { FT }\end{array}$} & \multirow{2}{*}{$\begin{array}{c}\text { PT : FT } \\
\text { t-test - P }\end{array}$} & \multirow{2}{*}{$\begin{array}{l}\text { EC : CC } \\
\text { t-test }-P\end{array}$} \\
\hline & FT & PT & & & \\
\hline $\begin{array}{l}\cdots \\
\text { understandable. }\end{array}$ & 3.7 & 4.5 & 2.9 & 0.00 & 0.00 \\
\hline $\begin{array}{l}\text {... well- } \\
\text { designed. }\end{array}$ & 3.4 & 4.3 & 3.5 & 0.00 & \\
\hline $\begin{array}{l}\text {... appropriately } \\
\text { comprehensive. }\end{array}$ & 3.4 & 3.7 & 2.5 & 0.00 & 0.00 \\
\hline Average & 3.5 & 4.2 & 3.0 & 0.00 & 0.00 \\
\hline $\begin{array}{l}\text { Would like } \\
\text { interactive } \\
\text { materials. }\end{array}$ & 2.7 & 3.0 & 2.2 & 0.02 & 0.00 \\
\hline $\begin{array}{l}\% \text { of material } \\
\text { printout. }\end{array}$ & 60.8 & 91.9 & 81.1 & 0.00 & 0.00 \\
\hline
\end{tabular}

Legend: ES - elective subject, CS - compulsory subject, FT - full time students, PT - part-time students

Similarly to the e-classroom acceptance, part-time students also more keenly accepted study materials. Part-time students (3.0) were more interested in interactive materials than full-time students $(2.7$ and 2.2). Students attending the compulsory course were not interested in interactive materials (2.2). Data gathered are even more interesting if we compare them with the share of material printout available through the online classroom. On average, students printed out $77.0 \%$ of study materials, which is less than in the previous research $[16,17]$, when students printed out on average $84 \%$ of them.

For the purpose of further research, we formed, by means of the method of main components, one variable from the variables given in Table 3 . The new variable, which was called materials, explains 70.77 $\%$ variance of combined variables.

Course delivery in e-classroom differs from the traditional classroom course delivery. Initial enthusiasm, which was noticed when we introduced the e-classroom for the first time, disappeared. Students know in advance what is to be expected in the on-line course delivery, because information about how on-line courses are delivered and student requirements are easily available in student forums. It is interesting to compare the answers regarding the difficulty of on-line and traditional course delivery. It was rather obvious that students had the feeling that they had to participate actively and that they had to work much harder than in other courses. On the other hand, they liked the flexible way of studying. Such course delivery made it easier for students to manage their other study and personal responsibilities, because they could participate in the e-classroom at different times and from different places. The comparison of opinions is given in Table 4.

Blended course delivery was exhausting or at least not easier mainly for students attending the compulsory course, who complained during office hours and in their e-mails that they had to work too hard. Otherwise, average student assessments regarding the invested efforts do not differ statistically (Table 4).

Table 4. Opinion on course delivery

\begin{tabular}{|c|c|c|c|c|c|}
\hline \multirow{2}{*}{$\begin{array}{l}\text { Course delivery } \\
\text { was... }\end{array}$} & \multicolumn{2}{|c|}{ EC } & & PT : FT & $E C: C C$ \\
\hline & FT & PT & FT & t-test - F & t-test $-P$ \\
\hline ... as expected. & 3.6 & 4.2 & 3.2 & 0.00 & 0.00 \\
\hline ... easier. & 3.4 & 3.7 & 2.9 & 0.01 & 0.00 \\
\hline ... more interesting. & 4.0 & 4.5 & 3.3 & 0.00 & 0.00 \\
\hline $\begin{array}{l}\ldots \text { more tiring than } \\
\text { traditional study. }\end{array}$ & 3.9 & 4.1 & 4.0 & & \\
\hline $\begin{array}{l}\ldots \text { cheaper than } \\
\text { traditional study. }\end{array}$ & 3.5 & 4.0 & 3.0 & 0.00 & 0.00 \\
\hline
\end{tabular}

Legend: ES - elective subject, CS - compulsory subject, FT - full time students, PT - part-time students

Variables related to on-line course delivery, shown on Table 4, were merged into one variable by using the method of principle components, which explains $57.32 \%$ variance of combined variables.

The model of blended e-learning differed with regard to elective and compulsory course, or the differences stemmed from the way of study. For part-time students, only two face-to-face sessions were organised. The first session is for students to get acquainted with each other and for presenting them the course delivery. The second session - and also the last one - is dedicated to student presentations and to a discussion about the course delivery. Students attending the compulsory course were unanimous in saying that the number of sessions is too high (6 in 12 weeks). Only $20 \%$ of students attending the compulsory course proposed more than 6 sessions. On average, students wanted 4.8 face-to- 
face sessions or $40 \%$ of planned traditional sessions. Students attending the elective course wanted, on average, 2.9 sessions (part-time students) or 3.4 sessions (full-time students). Taking into account that the course lasted eight weeks, this represents between 36.3 to $42.5 \%$ of sessions. We believe that at least two sessions are necessary, but an additional session during the course would prove useful, because it may have a positive influence on the motivation of students.

As seen from Table 5, full-time students wanted more face-to-face sessions, because face-to-face sessions are an opportunity to socialize with their fellow students. On the other hand, part-time students find it difficult to attend face-to-face sessions, because of their professional and family responsibilities. The difference is statistically significant $(\mathrm{P}=0.00)$.

Table 5. Opinion about face-to-face sessions

\begin{tabular}{lccc}
\hline Variables & \multicolumn{2}{c}{ EC } & CC \\
& FT & PT & FT \\
\hline $\begin{array}{l}\text { We would like to study } \\
\text { in this way. }\end{array}$ & 3.6 & 4.2 & 3.0 \\
$\begin{array}{l}\text { The number of } \\
\text { sessions could be } \\
\text { smaller. }\end{array}$ & 3.4 & 2.9 & 5.0 \\
$\begin{array}{l}\text { Desired \% of face-to- } \\
\text { face sessions. }\end{array}$ & 42.5 & 36.3 & 40.0 \\
\hline
\end{tabular}

Legend: ES - elective subject, CS - compulsory subject, FT - full time students, PT - part-time students

In the elective course, the final success of students depended on their success during planned weekly activities. The activities were more keenly accepted by students attending the elective course than by students attending the compulsory course (Table 6). Part-time students saw the practical orientation of the course in the weekly activities. Full-time students are too used to learn only before the examinations and did not like to be involved in so many activities every week.

By using the method of principle components, variables connected with study activities were merged into one variable, which explains $54.88 \%$ variance of combined variables.
Table 6. Opinion of students about study activities

Variables

EC CC PT : FT EC : CC

FT PT FT t-test - P t-test - P

I got used to the

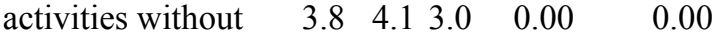

any problems.

Activities were not

too demanding.

$\begin{array}{lllll}2.9 & 3.4 & 2.2 & 0.00 & 0.00\end{array}$

Activities were

clearly defined.

$\begin{array}{lllll}3.4 & 4.1 & 3.2 & 0.00 & 0.00\end{array}$

Involvement in

activities suited me.

$\begin{array}{lllll}3.9 & 4.3 & 3.4 & 0.00 & 0.00\end{array}$

Group work did not

cause any

$\begin{array}{lll}3.7 & 3.8 & 3.1\end{array}$

0.00

problems.

$\begin{array}{llllll}\text { There were not too } & 3.3 & 4.1 & 2.5 & 0.00 & 0.00\end{array}$

many activities.

Activities are

practically oriented.

Average

$\begin{array}{llll}3.7 & 4.4 & 3.3 & 0.00\end{array}$

0.00 FT - full time students, PT - part-time students

The effectiveness of the learning process was tested with the course assessment and the opinion about the acquired knowledge. The course assessment presents the assessment of all study activities, in which students participated in e-classroom. Because knowledge in social sciences is more difficult to measure than, say, in natural sciences or technology, students expressed their views in terms of more or less knowledge acquired during blended learning. The assessment of acquired knowledge was done on a 5 -level scale $(5=$ acquired more knowledge, $1=$ acquired less knowledge).

Table 7. The assessment of exam exercises and the opinion about acquired knowledge

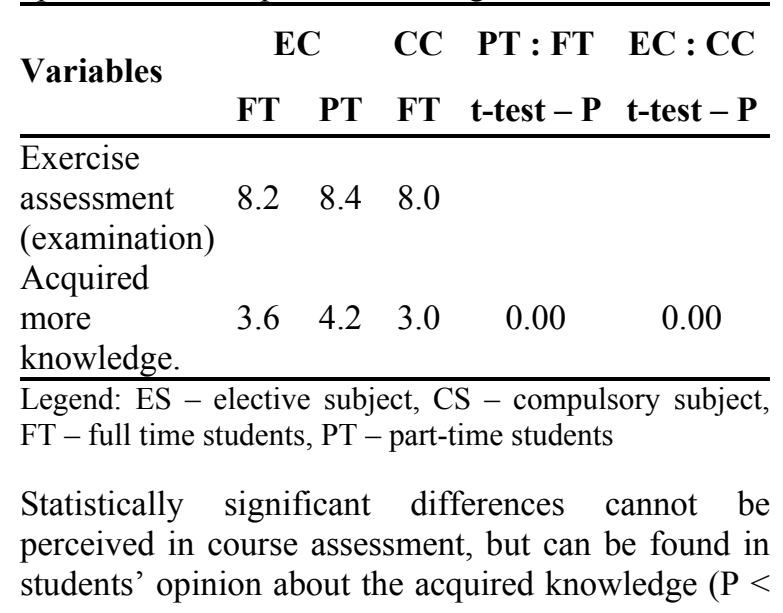


0.05). Students attending the elective course acquired more knowledge.

For the newly formed variables we tested the correlation of variables with course assessment and the opinion about the acquired knowledge.

Table 8. The correlation between the characteristics of blended learning, course assessment and the opinion about the acquired knowledge

\begin{tabular}{|c|c|c|c|c|}
\hline Variables & 1. & 2. & 3. & 4. \\
\hline \multicolumn{5}{|l|}{ 1. E-classroom } \\
\hline 2. Materials & $0.61 * *$ & & & \\
\hline $\begin{array}{l}\text { 3. Course } \\
\text { delivery }\end{array}$ & $0.63 * *$ & $0.73 * *$ & & \\
\hline 4. Activities & $0.71 * *$ & $0.81 * *$ & $0.77 * *$ & \\
\hline $\begin{array}{l}\text { 5. Desired } \% \text { of } \\
\text { face-to-face } \\
\text { sessions } \\
6 . \text { Course }\end{array}$ & & & $-0.20 * *$ & $-0.15^{*}$ \\
\hline $\begin{array}{l}\text { assessment } \\
\text { 7. Acquired } \\
\text { knowledge }\end{array}$ & $0.54 * *$ & $0.62 * *$ & $0.69 * *$ & $0.64 * *$ \\
\hline $\begin{array}{lll}\text { Legend: } & * * & \text { sta } \\
\mathrm{P}=0.01, & * & \text { stat } \\
\mathrm{P}=0.05 & & \end{array}$ & $\begin{array}{l}\text { istically } \\
\text { stically }\end{array}$ & $\begin{array}{l}\text { signifi } \\
\text { signific }\end{array}$ & $\begin{array}{ll}\text { nnt } & \text { corr } \\
\text { nt } & \text { corre }\end{array}$ & $\begin{array}{l}\text { lation } \\
\text { lation }\end{array}$ \\
\hline
\end{tabular}

Students, who keenly accepted e-classroom and study materials, believed that they acquired more knowledge through blended learning (0.54 or 0.62 ). The same opinion was expressed by students, who were satisfied with the course delivery (0.69) and students, who did not have any problems with activities (0.64). Students, who did not like either the course delivery or activities, desired more face-toface sessions. On the other hand, students who liked the course delivery and activities desired fewer sessions (-0.20 and -0.15$)$, because studying in an online classroom did not cause any problems.

It is interesting, though, that in our analysis we could not find any influences of individual course deliveries on course assessment, but only on the opinion about the acquired knowledge. Next, we tested the direct influence of variables on the opinion about the acquired knowledge with the regression analysis (Table 9).

E-classroom, study materials and the delivery of elearning explain $52.4 \%$ variability of the opinion about the acquired knowledge, when other conditions are unchanged. The greatest influence on the opinion about the acquired knowledge can be ascribed to the acceptability of e-learning delivery (it explains 49.3 $\%$ variability of the opinion about the acquired knowledge).
Table 9. Blended learning - linear regression analysis (dependable variable: opinion about the acquired knowledge)

\begin{tabular}{lccc}
$\begin{array}{l}\text { Included } \\
\text { variables }\end{array}$ & $\mathbf{B}$ & $\mathbf{t}$ & $\mathbf{P}$ \\
\hline $\begin{array}{l}\text { Delivery of e- } \\
\text { learning }\end{array}$ & 0.556 & 5.807 & 0.000 \\
Materials & 0.210 & 2.189 & 0.030 \\
E-classroom & 0.173 & 2.033 & 0.044 \\
\hline $\begin{array}{l}\text { F=62.318 Sig. } \\
\text { 0.000 R } \mathrm{R}^{2}=0.524\end{array}$ \\
$\begin{array}{l}\text { Excluded variables: activities, desired \% of face- } \\
\text { to-face sessions }\end{array}$
\end{tabular}

\section{CONCLUSION}

Our research proved that the acceptability of elearning delivery, the acceptability of materials and e-classroom have a statistically significant influence on the acquired knowledge, which means that these characteristics should be taken into consideration and, above all, thoroughly studied. The frequency of face-to-face sessions itself does not have a statistically significant influence on the opinion about the acquired knowledge, but we nevertheless believe that we should have face-top-face sessions with students at least two ore three times during the course.

Our research:

$\square$ proved the hypothesis H1 that ICT introduction in education requires different teaching strategies, because course delivery has a statistically significant influence on the opinion about the acquired knowledge.

$\square$ proved the hypothesis $\mathrm{H} 2$ that students acquire more knowledge, because statistically significant differences appeared with regard to the opinions about the acquired knowledge. Especially students who attended elective courses and who studied part-time acquired more knowledge during the blended learning than in traditional learning. With regard to Russell (2001, NSD 2006), who claims that there are no statistically significant differences in acquired knowledge among traditional and online course delivery, our findings may be different because of the fact that students acquired knowledge that was not directly connected with the course. They mainly acquired skills enabled by the use of ICT in education group work, communication skills, computer and Internet related skills.

did not prove the hypothesis $\mathrm{H} 3$ that students, who had the opportunity to experience more faceto-face sessions with their fellow students and the teacher, became more effective than their fellow 
students, who were deprived of such opportunities.

Our research proved that blended learning, which involves different teaching strategies than traditional education improves study effectiveness and represents a suitable course delivery for part-time students, mainly due to time and spatial adaptability of the study process.

\section{REFERENCES}

1. Ally, Mohamed. 2004. Foundations of Educational Theory for Online Learning. V Anderson, Terry in Fathi Elloumni (2004, 3-31).

2. Anderson, Terry in Fathi Elloumni. ur. 2004. Theory and Practise of Online Learning. Athabasca: Athabasca University, Canada.

3. Clark, Richard E. (1993). Media Will Never Influence Learning. Dostopno: http://www.usq.edu.au/material/unit/resource/cla rk/media.htm [9. 6. 2006].

4. Dagger, Declan in Vincent P. Wade. (2004). Evaluation of Adaptive Course Construction Toolkit (ACCT). Dostopno: http://wwwis.win.tue.nl/ acristea/AAAEH05/pa pers/6- a3eh_daggerd_IOS_format_v1.1.pdf [31. 8. 2006].

5. Eurostat - Statistical Office of the European Communities.

http://epp.eurostat.cec.eu.int/portal/page?_pageid $=1090,30070682,1090 \_30298591 \& \_$dad $=$portal \&_schema=PORTAL [21. 1. 2007].

6. HKGCC - Hong Kong General Chamber of Commerce. Edport.com. Dostopno: http://www.chamber.org.hk/info/member_a_wee k/edport.asp [2. 6. 2002].

7. IDC - Analyze for Future. Corporate Learning and Performance. An IDC Continuous Intelligence Service. Dostopno: http://www.idc.com/getdoc.jsp?containerId=IDC P415 [19. 8. 2006].

8. InternetTime Group. Dostopno: http://www.internettime.com/ [2. 6. 2002].

9. Mungania, Penina. 2004. Employees' perceptions of barriers in e-learning: The relationship among barriers, demographics, and e-learning self-efficacy - doktorat znanost. Kentucky: University of Lousville.

10. NSD - No Significant Difference Phenomenon. Dostopno: http://www.nosignificantdifference.org/ [12. 6 . 2006].

11. Overton, Laura. (2004). Linking Learning to business, Summary report 2004. BIZMedia. Dostopno
http://www.elearningage.co.uk/docs/LinkSumma ry.pdf [14. 4. 2006].

12. Russell, Thomas. L.. 2001. The No Significant Difference Phenomenon: A Comparative Research Annotated Bibliography on Technology for Distance Education. IDECC - International Distance Education Certification Center.

13. SURS - Statistični urad Republike Slovenije. (2002). Statistični letopis Republike Slovenije. Dostopno:

http://www.sigov.si/zrs/leto02/kazalo02.htm [11. 11. 2003].

14. SURS - Statistični urad RS. (2006). Vpis študentov na terciarno izobraževanje $v$ študijskem letu 2005/06 - končni podatki. 13. 4. 2006. Dostopno: http://www.stat.si/novice poglej.asp?ID=1027 [29. 30. 2006].

15. Sulčič, V., D. Lesjak, N. Trunk Šrca in P. Purg. 2005. Key issues of introducing blended learning in higher education. V: Proceedings of the IADIS international conference on Cognition and exploratory learning in digital age (CELDA 2005), Porto, Portugal, December 14-16, 2005. [Porto]: IADIS Press, cop. 2005, str. 449-454.

16. Sulčič, Viktorija. 2007. Is e-learning more suitable for full-time or for part-time students? V Technologies for Business Information Systems, ed. Abramowicz W., Mayr, H.C.. Heidelberg: Springer Verlag.

17. Trunk Širca, N. in V. Sulčič. 2003. Lifelong Learning and Higher Education Institutions; from Strategic Principle through Impelemented Example to Systematic Solution? V Knowledge Society - Challenges to Management; Globalisation, Regionalism and EU Enlargement Process. 4th International Conference of the Faculty of Management Koper, University of Primorska. 20. - 22. november 2003, Portorož. Koper: Fakulteta za management.

18. Vasquez B. S.. 2000. Linking Information Technology and Pedagogical Innovation To Enchance Management Education. V ECIS 2000 - A Cyberspace Odyssey, vol.2. Wien: Wirtscaftsuniversität. 